\title{
Leadership Theory: A Different Conceptual Approach
}

\author{
William E. Allen, Ph.D. \\ Assistant Professor \\ Fort Hays State University
}

\begin{abstract}
Creating a logical and consistent picture of the state of leadership theory and research is a difficult task (Hernandez, Eberly, Avolio, \& Johnson, 2011). Attempts to describe leadership studies occasionally include words such as "paradox," "inconsistencies," "contradictions," and "messy" (Brungardt, 1996; Klenke, 1993). These adjectives flow from many diverse ways of thinking about leadership (Bass, 2008; Grint, 2000; Northouse, 2015; Ruben, 2012). This paper presents an alternative view of leadership theory providing practitioners, educators, and students with an additional-and perhaps a singular-conceptual framework for their toolbox. It also provides leadership studies students with a unifying perspective of leadership theory without taking anything away from individual theories.
\end{abstract}

\section{Introduction}

This idea for a thirty-thousand-foot alternative view of leadership theory developed out of the challenges associated with teaching leadership studies concepts in China cross-culturally to Chinese students. The understanding of leadership theory that follows allows the reader to grasp the depth and breadth of discipline content in a way that makes sense from a holistic perspective. The new point of view encourages discussion with the hope for a more efficacious understanding of leadership theory in any part of the world. Prior papers have noted this same need and interest (Harter, 2012; Martin \& Allen, 2016; Paxton \& Van Stralen, 2016; Perkins, 2009). Moreover, this paper answers the call for a critical perspective that goes well beyond the currently available approach by addressing core assumptions in the field (Tourish, 2015).

The debate continues, though less over time, as to whether leadership studies education is a genuine discipline (Andenoro, 2013a). For leadership studies, that problem highlights the great strength of being transdisciplinary (Andenoro, 2013b). Leadership scholars identify the essential need to continue to build the foundation of the discipline for the next generation of leaders with a transdisciplinary perspective (Collier \& Rosch, 2016). This understanding acknowledges the challenges related to the way forward for all demographic groups with regard to leadership theory and practice (Collier et al., 2016).

As a discipline, leadership studies arguably includes paradoxes, inconsistencies and contradictions (Brungardt, 1996; Klenke, 1993). Bennis (1959) referred to the discipline subject matter as "hazy", and Burns (1978a) called leadership the most studied and least understood topic of any in the social sciences. After volumes of writing on leadership, generally accepted concepts of leadership remain elusive (Bennis, 1959). Charges of having an inconsistent approach to scholarship and lacking in empirical support also highlight the challenges in leadership studies (Hannah \& Avolio, 2010; Martin et al., 2016). In fairness, the difficulty in coming to an agreement on concepts or even a definition of leadership (Doh, 2003; Gill, 2006; 
Middlebrooks \& Allen, 2009; Nahavandi, 2006) owes to its inevitably interdisciplinary nature (Andenoro, 2013b). That fact underscores the lack of agreement as to the next stage of development in the discipline (Hernandez et al., 2011).

The standard way of teaching leadership theory through the chronological approach (Omilion-Hodges \& Wieland, 2016) enables students to appreciate the advances made in each successive theory. This method however generates the possibility students will fail to fully appreciate the continuing march of theories, and instead see them as competing rather than as complimentary and interdependent (Omilion-Hodges et al., 2016). Challenges markedly increase in the cross-cultural classroom environment where the understanding of power relations (Cheng, Chou, Wu, Huang, \& Farh, 2004), power distance (Carl, Gupta, \& Javidan, 2004), and collectivism versus individualism (Hofstede \& Hofstede, 2005) often clash with Western culture and theory. Honesty versus harmony (Perkins, 2009), long-term orientation versus short-term orientation (Hofstede et al., 2005), uncertainty avoidance (De Luque \& Javidan, 2004) and basic mores in the local culture provide additional hurdles for the same reasons. The need for the development of Cultural Intelligence (CQ) therefore becomes a two-way street (Livermore, 2011) for English as Second Language (ESL) students as well as for Western educators.

In addition, the prevalence of Chinese students on American campuses (more than $31 \%$ of all international students) (Collier et al., 2016) begs for an approach in leadership studies education that embraces a marriage of Eastern and Western worldviews. The historically low priority placed on developing programs sensitive to the needs of the ESL student exacerbates student-learning difficulties (Lee \& Rice, 2007; Shek \& Lin, 2016). The global need for competent leaders (Avery, 2004; Osland, Bird, \& Oddou, 2012), and the opportunity for leadership studies education to provide the way forward to a new paradigm (Paxton et al., 2016), directs attention beyond the Western classroom. That attention ought to include efforts to discern a framework for understanding leadership theory that can speak to all audiences with clarity and straightforward application.

This paper offers a tool for addressing these concerns and needs. This discussion looks backward to be able to look forward (Hunt \& Dodge, 2000), with an eye toward the essentials of leadership studies content (Andenoro, 2013a), and from a point of view on leadership knowledge (Harter, 2012) different from that historically taken. Furthermore, where authors have argued for a macro blending of leadership theory with institutional and organizational theories under complexity theory (Shoup, 2017), this paper takes the same approach albeit on a micro level within the leadership discipline.

\section{Review of Related Scholarship}

Effective business leaders today must have "people skills" (Saloner, 2010). The very nature of that phrase implies leaders should know how to get along with people of varied backgrounds, beliefs, and origins. This emphasizes the importance of personality, and the understanding that people intuitively act as psychologists attempting to explain and predict other peoples' behavior (Repacholi, Meltzoff, Toub, \& Ruba, 2016). In this process, we attribute certain traits to people based on what we see, hear, and understand and thereby link perceived behavior to those trait characteristics (Heider, 1958). We learn to do this from infancy 
(Repacholi et al., 2016) as a protective function (Rozin \& Royzman, 2001), and thereafter are well on our way to forming realized or unrealized stereotypes (Repacholi et al., 2016) that help us navigate the world. Being able to override these instincts to provide time to reflect and respond less impulsively comes most directly through maturity (Bartholow, Dickter \& Sestir, 2006). That maturation process disrupts the causal straight line drawn between traits and perceived behaviors (Asch, 1946). Simply spending time with a person enables us to form a more comprehensive narrative about them (Adler \& McAdams, 2007).

The operative word mentioned above is, "traits." That term refers to those consistent patterns of thoughts, feelings, and behaviors we associate with people including ourselves (McCrae \& Costa, 2003). Traits also represent the basic tendencies we use to adapt to our environment including interaction with other people (McCrae \& Costa, 1999). For the purpose of this paper, the reader is asked to disengage from negative connotations associated with the word, "traits" due to the early leadership study emphasis on Trait Theory and the axiom, "Great leaders are born not made" (Thomas, 2010). This discussion rejects that myth.

Further difficulty comes from the view that traits as biologically programmed attributes cannot be altered (McCrae \& Costa, 2008). The broader view tells us that personality traits though being relatively stable (Asendorpf, 1992), can change (Hudson, Roberts, \& Lodi-Smith, 2012). Moreover, most people desire change and even set goals in that effort (Hudson \& Roberts, 2014). Commitments to adopt a new personality trait may be the first step in realizing a trait change by building upon a new perception of self, resulting in the acquisition of the trait desired (Lodi-Smith and Roberts, 2007). Self-initiated changes reflect conscious new patterns in thinking, feeling, and behaving that eventually may form into lasting trait changes (Magidson, Roberts, Collado-Rodriguez, \& Lejuez, 2012). That is why, for example, students might select extra-curricular activities they hope will equip them with new personality traits such as leadership (Stevenson \& Clegg, 2011). Even where no active effort to change personality traits exists, changes occur through the biological maturation process often as a response to changing roles (Roberts, Walton, \& Viechbauer, 2006).

The resurging interest in traits acknowledges their primary place in leadership theory (Antonakis, Day, \& Schyns, 2012; Northouse, 2007). The difficulty in applying traits to leadership theory or vice versa stems from the more than 15,000 personality trait adjectives in the English language (Goldberg, 1990). Nevertheless, leadership material has routinely compartmentalized theoretical understanding into traits, skills, and behaviors as the theoretical framework (Northouse, 2010; Rosch, Boyd, \& Duran, 2014). Add to that framework other often-used identifiers such as relationships, feelings, factors, viewpoints, characteristics, habits, competencies, dispositions, gifts, intelligences, capabilities, dimensions, determinants, responses, abilities, tendencies, etc. and the potential for overlap and confusion becomes exponential.

\section{Description of the Theoretical Approach}

We infer as traits, skills, and behaviors those characteristics we see in other people that we "attribute" to them based on the logical principles and cognitive processes we have come to rely upon (Carlston \& Skowronski, 2005). Attribution Theory outlines this process and provides an explanation for how we understand our world and function in it (Jones, Kannouse, Kelley, 
Nisbett, Valins, \& Weiner, 1972). Attributes therefore describe our understanding of other people (or ourselves) based on what we perceive through our senses and as filtered by our worldview. For the purpose of this discussion and for the remainder of this paper, "attribute" refers to each one of the thousands of single or compound adjectives previously subdivided into traits, skills, and behaviors in leadership theory. In other words, "attribute" refers to every conceivable word or phrase used to describe a leader.

Carlyle (1840) opined great men were responsible for the course of history and, based on that assumption, an examination of biographical accounts yielded presumed leadership attributes. Burns (1978b), considered the father of modern leadership study, identified attributes associated with leaders who transform society. Many others contributed along the way. Stogdill (1948) in his comprehensive review of leadership trait studies from 1907 to 1947 identified five personal characteristics (capacity, achievement, responsibility, participation, and status) influencing leadership effectiveness. Stogdill (1974) repeated the exercise in an update from 1948 to 1970 and published a list of twenty different attributes common among effective leaders. House (1977) proposed his Charismatic Theory with the identification of five attributes of charismatic leaders. Each time, research and theories led us to a new list of attributes characteristic of effective leaders.

Lewin and Lippitt (1938) started a conversation on the behavioral approach to understanding leadership, which resulted in the leadership behavioral styles of autocratic, democratic, and laissez-faire, each with an associated list of attributes. For a more comprehensive understanding, the University of Michigan assessed more than 500 studies to determine the effectiveness of autocratic leadership versus democratic leadership (Likert, 1961). That research identified four different systems of leadership with leader attributes in each system.

Similarly, Ohio State University distilled 1,800 descriptions of leader behavior to onehundred fifty that identified the attributes of good leaders (Hemphill, 1949). McGregor (1960) proposed the Theory $\mathrm{X}$ and Theory $\mathrm{Y}$ understanding of human motivation to identify attributes of leaders and their views on subordinates. Covey (1991) identified seven attributes (habits) of effective leaders and Goleman (1998) noted five Emotional Intelligence attributes.

At each step of the way with each new theory, it became apparent that good leadership could not be isolated to an overriding single trait or style (Crawford, Brungardt \& Maughan, 2005). Fiedler (1967) proposed the Contingency Model of leadership that examined leader task or relationship orientation and the related attributes. Hersey and Blanchard (1969) proposed the Situational Leadership Model to address the job and psychological maturity of workers and the leader's ability to adjust to those different needs. Here as well, a list of attributes associated with the effective leader proceeded from each model.

Others carried the study of leadership into different areas. French and Raven (1959) examined the ability of leaders to influence subordinates with different types of power, and Yukl (2002) examined influence tactics leaders might use. In each of these contributions, a list of attributes emerged to describe the effective leader. 
Rost's (1997) discussion of the Industrial Paradigm versus the Post-Industrial Paradigm listed leader attributes under each paradigm, as did Social Change Leadership Theory (Crislip \& Larson, 1994). Writing on Followership acknowledged followers and leaders could be interchangeable, and descriptions of the courageous follower (Chaleff, 1995) and the servant leader (Greenleaf, 1977) each offered lists of attributes describing the effective leader.

All theoretical approaches to leadership eventually yield a list of attributes associated with the effective leader. Notwithstanding other important aspects of leadership addressed in the theories, each approach to leadership relates back to the early starting point of leadership theory in its identification of effective leader attributes. Each theory added to the total attribute list with subsets necessary for leader effectiveness in different environments. The following discussion attempts to reframe leadership theory with the idea that we continually find ourselves back at the beginning, trying to add to or refine the list of attributes describing effective leaders.

Leadership study started out as an effort to identify attributes of effective leaders and progressed to descriptions of different perspectives and aspects of leadership. These consecutive contributions to the study of leadership presented various theoretical frameworks to increase understanding and as a platform for further work. Each step in the evolution of leadership theory at some point in the discussion listed attributes as a concise word picture for the effective leader. Each time a list of attributes emerged from a new theory, concomitant theoretical links back to the early days of leadership study emerged. Figure 1 is a graphic representation of this viewpoint.

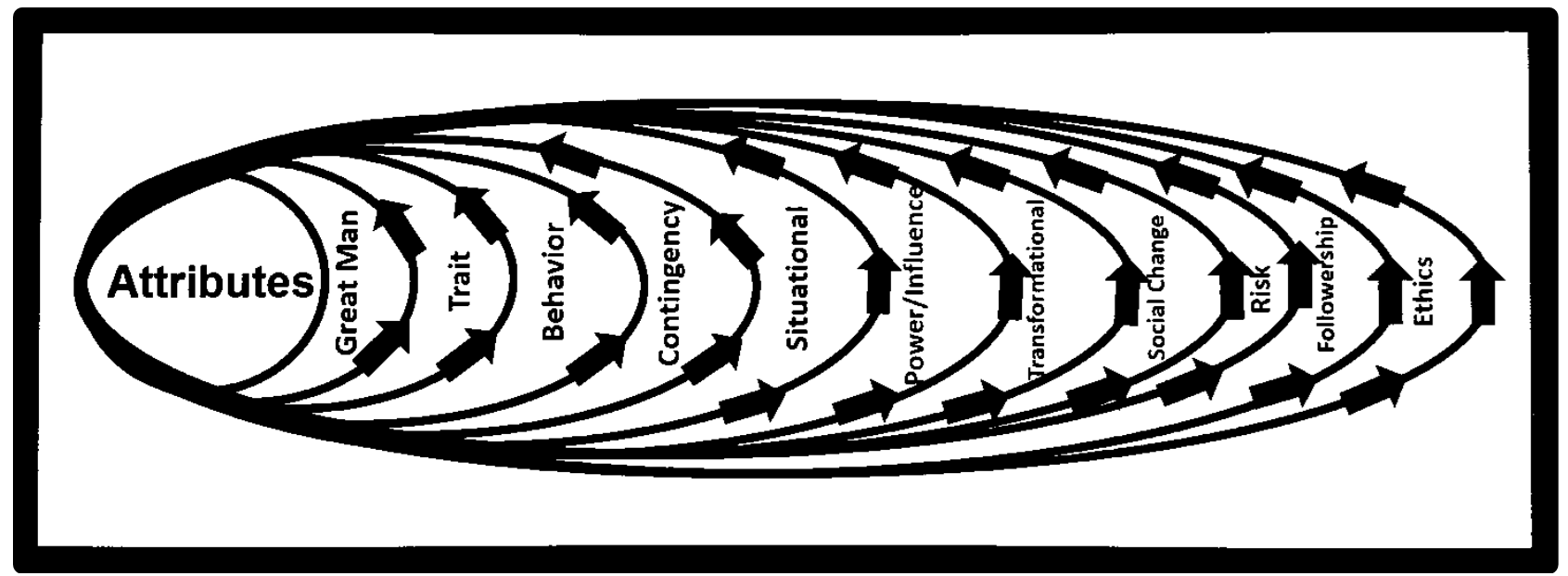

Figure 1. Leadership theory - A different conceptual approach

Figure 1 cannot logistically accommodate all leadership theories and does not imply a lesser or greater standing for any theory. Leadership study began with a focus on historical figures deemed to be great, followed by a study of traits associated with leaders, etc. At each point in the progression of leadership theory, the identification of effective leader attributes circled back to initial efforts to identify those things that were commonly found in effective leaders. 
Note, with this approach, the complete pool of attributes has always been there. Note also that each successive contribution to leadership theory drew from the pool of attributes to address a new perspective or subset of leader attributes, and that contribution therefore related back to the complete pool. Again, all the attributes a leader would ever need to be effective and successful existed in their entirety from the start. Those attributes include traits, skills, behaviors, etc. not yet known to humankind. For example, in 1930, no leader would have had to be competent with a computer and internet use to be effective, as would generally be the case today. Computer and internet use competence attributes however, were always present in the pool of attributes as are many others not even currently available or known.

The advantages of this new perspective on leadership theory are many. The complaints that leadership study includes paradoxes and inconsistencies and is messy, hazy, and inconsistent largely evaporate. Each theory benefits from the ability to select attributes from a complete pool for applying them to specific situations. This allows for a specific description of leadership in unique scenarios. The researcher, student, and practitioner can all understand the relationship of the specific application to the whole of leadership theory. Furthermore, the likelihood that students will view theories as competing diminishes for the same reason.

In addition, Burns' (1978a) observation that leadership is the most studied and least understood topic in any of the social sciences may no longer apply as it once did. Figure 1 enables the viewer to conceptualize leadership in its growing array of dimensions with clarity and utility. The complete pool of attributes, likely never to be known in its entirety, defies attempts to place a hierarchical order on the attributes because selection occurs as needed for theory, discussion, and application. The attributes do not "belong" to any one theory.

Perhaps the most useful advantage of this perspective comes from its potential elimination of Western cultural bias in leadership theory. Since all attributes exist in the pool, cultural barriers need not hamper selection of attributes for the understanding of leadership theory. Highly valued Asian attributes such as harmony, civility, friendship, and equality are not innately less important than honesty. With this new freedom, cross-cultural understanding and application of leadership theory allows for the potential availability of each attribute in every theoretical and cultural dimension. This new conceptual approach gives voice to the global academy for the continued development of leadership theory apart from the constraints of Western cultural bias.

\section{Future Research}

Future discussion and research should focus on the advantages and disadvantages of the proposal in this article. In addition, baskets of attributes could be constructed for each topic, perspective, situation, environment, etc. with a proposed cross-cultural superordinate attribute list. A reasonable approach in the classroom would also require each student to personally construct and justify those baskets of attributes based on course content and their own worldview. Those cross-cultural imperatives also justify work in leadership studies curriculum to guide students in the discovery of the foundational beliefs that form the premise of their worldview. 


\section{Conclusion}

This paper offers leadership researchers, educators, practitioners, and students an alternative for a holistic understanding of leadership. It is an additional conceptual approach, not a replacement. This approach however easily accommodates new theories and perspectives for the continued growth of leadership understanding, perhaps even into a three-dimensional model, where a truly global leadership perspective is achieved.

\section{References}

Adler, J. M., \& McAdams, D. P. (2007). Time, culture, and stories of the self. Psychological Inquiry. 18(2), 97-99.

Andenoro, A. (2013a). The Inaugural National Leadership Education Research Agenda: A new direction for the field. Journal of Leadership Education. 12(3), 1-9.

Andenoro, A. (2013b). The National Education Research Agenda: Strategic priorities and deepened perspectives. Journal of Leadership Education. 12(1), 1-9.

Antonakis, J., Day, D. V., \& Schyns, B. (2012). Leadership and individual differences: At the cusp of a renaissance. Leadership Quarterly. 23(4), 643-650.

Asch, S. E. (1946). Forming impressions of personality. Journal of Abnormal and Social Psychology. 41(3), 258-290.

Asendorpf, J. B. (1992). Beyond stability: Predicting inter-individual differences in interindividual change. European Journal of Personality. 6(2), 103-117.

Avery, G. (2004). Understanding leadership. Thousand Oaks: Sage.

Bartholow, B. D., Dickter, C. L., \& Sestir, M. A. (2006). Stereotype activation and control of race bias: Cognitive control of inhibition and its impairment by alcohol. Journal of Personality and Social Psychology. 90(2), 272-287.

Bass, B. M. and Bass, R. (2008). The Bass handbook of leadership: Theory, research, and managerial applications $\left(4^{\text {th }}\right.$ ed.). New York: Free Press.

Bass, B. M., Steidlmeier, P. (1999). Ethics, character, and authentic transformational leadership behavior. Leadership Quarterly. 10(2), 181-217.

Bennis, W. G. (1959). Leadership theory and administrative behavior. The problem of authority. Administrative Science Quarterly. 4(3), 259-310.

Brungardt, C. (1996). The making of leaders: A review of the research in leadership development and education. Journal of Leadership Studies. 3(3), 82. 
Burns, J. M. (1978a). Leadership. New York: Free Press.

Burns, J. M. (1978b). Transformational leadership. New York: Harper \& Row.

Carl, D., Gupta, V., \& Javidan, M. (2004). Power Distance. In R. J. House, P. J. Hanges, M. Javidan, P. W. Dorfman \& V. Gupta (Eds.), Culture, leadership and organizations: The GLOBE study of 62 societies (pp. 513-563). Thousand Oaks: Sage.

Carlston, D. E., \& Skowronski, J. J. (2005). Linking versus thinking: Evidence for the different associative and attributional bases of spontaneous trait transference and spontaneous trait inference. Journal of Personality and Social Psychology. 89(6), 884-898.

Carlyle, T. [1840] (1888). On heroes, hero-worship and the heroic in history. New York: Frederick A. Stokes \& Brother.

Chaleff, I. (1995). The courageous follower: Standing up to and for our leaders. San Francisco: Barrett-Koehler.

Cheng, B. S., Chou, L. F., Wu, T. Y., Huang, M. P., \& Farh, J. L. (2004). Paternalistic leadership and subordinate responses: Establishing a leadership model in Chinese organizations. Asian Journal of Social Psychology. 7(1), 89-117.

Collier, D. \& Rosch, D. (2016). Effects associated with leadership program participation in international students compared to domestic students. Journal of Leadership Education. 15(4), 33-49.

Cover, S. R. (1991). Principle-centered leadership. New York: Summit.

Crawford, C. B., Brungardt, C. L., \& Maughan, M. R. C. (2005). Understanding leadership: Theories and concepts. ( $3^{\text {rd }}$ ed.). Hoboken: Wiley \& Sons.

Crislip, D. D., \& Larson, C. E. (1994). Collaborative leadership: How citizens and civic leaders can make a difference. San Francisco: Jossey-Bass.

De Luque, M. S. \& Javidan, M. (2004). Uncertainty avoidance. In R. J. House, P. J. Hanges, M. Javidan, P. W. Dorfman \& V. Gupta (Eds.), Culture, leadership and organizations: The GLOBE study of 62 societies (pp. 602-653). Thousand Oaks: Sage.

Doh, J. P. (2003). Can leadership be taught? Perspectives from management educators. Academy of Management Learning and Education. 2(1), 54-67.

DuBrin, A. J. (2010). Leadership: Research, practice, and skills. Boston: Houghton Mifflin.

Fiedler, F. E. (1967). A theory of leadership effectiveness. New York: McGraw Hill. 
French, J. R., \& Raven, B. (1959). The bases of social power. In Studies in social power (pp. 150-167). Ann Arbor: University of Michigan Press.

Gill, R. (2006). Theory and practice of leadership. London: Sage.

Goldberg, L. R. (1990). An alternative "description of personality": The big-five factor structure. Journal of Personality and Social Psychology. 59(6), 1216-1229.

Goleman, D. (1998). Working with emotional intelligence. New York: Bantam.

Greenleaf, R. (1977). Servant leadership. New York: Paulist Books.

Grint, K. (2000). The arts of leadership. Oxford: Oxford University Press.

Hannah, S. \& Avolio, B. J. (2010). Ready or not: How do we accelerate the developmental readiness of leaders? Journal of Organizational Behavior. 31(8), 1181-1187.

Harter, N. (2012). Point of view: Leadership studies from different perspectives. Journal of Leadership Education. 11(2), 158-175.

Heider, F. (1958). The psychology of interpersonal relations. Hoboken: Wiley.

Hemphill, J. K. (1950). Leader behavior description. Columbus: Ohio State University, Personnel Research Board.

Hernandez, M., Eberly, M. B., Avolio, B. J., \& Johnson, M. D. (2011). The loci and mechanisms of leadership: Exploring a more comprehensive view of leadership theory. The Leadership Quarterly. 22(6), 1165-1185.

Hersey, P., \& Blanchard, K. H. (1969). Life cycle theory of leadership. Training and Development Journal. 23(2), 26-34.

Hofstede, G., \& Hofstede, G. J. (2005). Cultures and organizations: Software of the mind. New York: McGraw-Hill.

House, R. J. (1977). A 1976 theory of charismatic leadership. In J. G. Hunt \& L. L. Larson (Eds.), Leadership: The cutting edge (pp. 189-207). Carbondale: Southern Illinois University.

Hudson, N. W., \& Roberts, B. W. (2014). Goals to change personality traits: Concurrent links between personality traits, daily behavior, and goals to change oneself. Journal of Research in Personality. 53(1), 68-83.

Hudson, N. W., Roberts, B. W., \& Lodi-Smith, J. (2012). Personality trait development and social investment in work. Journal of Research in Personality. 46(3), 334-344. 
Hunt, J. G., \& Dodge, G. E. (2000). Leadership déjà vu all over again. Leadership Quarterly. 11(4), 435-458.

Jones, E. E., Kannouse D. E., Kelley, H. H., Nisbett, R. E., Valins, S, \& Weiner, B. (Eds.) (1972). Attribution: Perceiving the causes of behavior. Morristown: General Learning Press.

Klenke, K. (1993). Leadership education at the great divide: Crossing in to the twenty first century. Journal of Leadership \& Organizational Studies. 1(1) 111-127.

Kohlbery, L. (1984). Essays on moral development: The nature and validity of moral stages. Vol. 2. San Francisco: Harper \& Row.

Kouzes, J., \& Posner, B. (1987). The Leadership challenge. San Francisco: Jossey-Bass.

Lee, J. J., \& Rice, C. (2007). Welcome to America? International student perceptions of discrimination. Higher Education. 53(3), 381-409.

Lewin, K., \& Lippitt, R. (1938). An experimental approach to the study of autocracy and democracy: A preliminary note. Sociometry. 1(1), 292-300.

Likert, R. (1961). An emerging theory of organizations, leadership and management. In L. Petrullo \& B. M. Bass (Eds.), Leadership and interpersonal behavior (pp. 201-215). New York: Holt, Rinehart \& Winston.

Livermore, D. (2011). The cultural intelligence difference. New York: AMACOM.

Lodi-Smith, J., \& Roberts, B. W. (2007). Social investment and personality: A meta-analysis of the relationship of personality traits to investment in work, family, religion, and volunteerism. Personality and Social Psychology Review. 11(1), 68-86.

London, M., \& Maurer, T. J. (2004). Leadership development: A diagnostic model for continuous learning in dynamic organizations. In J. Antonakis, A. Cianciolo \& R. Sternberg (Eds.), The Nature of leadership (Chap. 10). Thousand Oaks: Sage.

Magidson, J. F., Roberts, B. W., Collado-Rodriguez, A., \& Lejuez, C. W. (2012). Theory-driven intervention for changing personality: Expectancy value theory, behavioral activation, and conscientiousness. Developmental Psychology. 50(5), 1-9.

Martin, B., \& Allen, S. (2016). Empirical test of the know, see, plan, do model for curriculum design in leadership education. Journal of Leadership Education. 15(4), 132-143.

McCrae, R. R., \& Costa, P. T., Jr. (1999). A five-factor theory of personality. In L. A. Pervin \& O. P. John (Eds.), Handbook of personality: Theory and research ( $2^{\text {nd }}$ ed., pp. 159-181). New York: Guilford Press. 
McCrae, R. R., \& Costa, P. T., Jr. (2003). Personality in adulthood: A five-factor theory perspective ( $2^{\text {nd }}$ ed.). New York: Guilford Press.

McCrae, R. R., \& Costa, P. T., Jr. (2008). The five-factor theory of personality. In L. A. Pervin \& O. P. John (Eds.), Handbook of personality: Theory and research $\left(3^{\text {rd }}\right.$ ed., pp. 150181). New York: Guilford Press.

McGregor, D. (1960). The human side of enterprise. New York: McGraw Hill.

Middlebrooks, A., \& Allen, S. J. (2009). The education of leadership. Journal of Leadership Education. 8(1), viii-xxii.

Myers, L. A. (2005). Preparing for ethical leadership: A longitudinal study. Journal of Leadership Education. 14(2), 146-160.

Nahavandi, A. (2006). Teaching leadership to first-year students in a learning community. Journal of Leadership Education. 5(2), 14-27.

Northouse, P. G. (2007). Leadership: Theory and practice ( $4^{\text {th }}$ ed.). Thousand Oaks: Sage.

Northouse, P. G. (2010). Leadership: Theory and practice ( $5^{\text {th }}$ ed.). Thousand Oaks: Sage.

Northouse, P. G. (2015). Leadership: Theory and practice ( $7^{\text {th }}$ ed.). Thousand Oaks: Sage.

Omilion-Hodges, L. M., \& Wieland, S. M. B. (2016). Unraveling the leadership dichotomy in the classroom and beyond. Journal of Leadership Education. 15(1), 110-128.

Osland, J. S., Bird, A., \& Oddou, G. R. (2012). The context of expert global leadership. In W. H. Mobley, Y. Wang, and M. Li (Eds.) Advances in global leadership, vol. 7. Oxford: Elsevier.

Paxton, D. \& Van Stralen, S. (2016). Developing collaborative and innovative leadership: Practices for fostering a new mindset. Journal of Leadership Education. 14(4), 11-25.

Perkins, A. W. (2009). Global leadership study: A theoretical framework. Journal of Leadership Education. 8(2), 72-87.

Posner, B. Z. (2009). From inside out: Beyond teaching about leadership. Journal of Leadership Education. 8(1), 1-10.

Roberts, B. W., Walton, K. E., \& Viechbauer, W. (2006). Patterns of mean-level change in personality traits across the life course: A meta-analysis of longitudinal studies. Psychological Bulletin. 132(1), 1-25. 
Rosch, D. M., Boyd, B. L., \& Duran, K. M. (2014). Students' self-identified long-term leadership development goals: An analysis by gender and race. Journal of Leadership Education. 13(3), 17-33.

Rost, J. C. (1997). Moving from industrial to relationship: A post-industrial paradigm of leadership. Journal of Leadership Studies. 4(4), 3-16.

Repacholi, B. M., Meltzoff, A. N., Toub, T. S., \& Ruba, A. L. (2016). Infants' generalizations about other people's emotions: Foundations for trait-like attributions. Developmental Psychology. 52(3), 364-378.

Rozin, P., \& Rozyman, E. B. (2001). Negativity bias, negativity dominance, and contagion. Personality and Social Psychology Review. 5(4), 296-320.

Ruben, B. D. (2012). What leaders need to know and do: A leadership competencies scorecard. ( $2^{\text {nd }}$ ed.). Washington, DC: National Association of College and University Business Officers.

Saloner, G. (2010). Building the next generation business leader. McKinsey Quarterly. April. Retrieved on September 16, 2017 at http://www.edbatista.com/files/2010/04/GarthSaloner-on-Leadership-2010.pdf.

Shek, D. T. \& Lin, L. (2016). Changes in university students after joining a service leadership program in China. Journal of Leadership Education. 15(1), 96-109.

Shoup, J.R. (2017). Leadership, organizational, and institutional studies; reconciling and teaching competing perspectives. Journal of Leadership Education. 15(4).

Stevenson, J., \& Clegg, S. (2011). Possible selves: Students orienting themselves toward the future through extracurricular activity. British Educational Research Journal. 37(2), 231246.

Stogdill, R. M. (1974). Handbook of leadership: A survey of theory and research. New York: Free Press.

Stogdill, R. M. (1948). Personal factors associated with leadership: A survey of the literature. Journal of Psychology. 25(1), 35-71.

Thomas, J. J. (2010). Bet you never heard of this leadership trait. Journal of Leadership Education. 9(2), 1-3.

Tourish, D. (2015). Some announcements, reaffirming the critical ethos of Leadership, and what we are looking for in submissions. Leadership. 11(1), 135-141.

Yukl, G. A. (2002). Leadership in organizations. $5^{\text {th }}$ ed. Englewood Cliffs: Prentice Hall. 


\section{Author Biography}

William E. Allen (weallen3@fhsu.edu) is an associate professor of organizational leadership for Fort Hays State University in Hays, Kansas with fulltime teaching responsibilities at a partner university in China. His current research interests focus on cross-cultural understanding in the areas of pedagogy, leadership and management theory, and leader development and behavior. 